\title{
Selection of Karanja Biodiesel Blend for Engine Performance by using TOPSIS and VIKOR Method
}

\author{
Mukul Agarwal, Shailendra Kumar
}

\begin{abstract}
Demand for energy is increasing due to the development of industries, expanding urbanization, and population growth which further increases the use of fossil fuel in large amount. This also affects an environmental pollution and engine sector too. In internal combustion (IC) engines, alternative fuel blends has one of the most important decision for balancing a number of opinions and criteria for making different strategic decision by an engine expert. Choice of alternative sources of suitable blending of biodiesel and biodiesel plays an important role in engine sector. In this paper, discuss the Multi Criteria Decision Making (MCDM) techniques is used for selecting the best alternative blend of Karanja methyl ester biodiesel to fulfil the demand in IC engine sector. Optimization was done by using of VIKOR (Visekriterijimsko Kompromisno Rangiranje) and TOPSIS (technique for order performance by similarity to ideal solution) techniques. The parameter considered for optimization includes brake thermal energy, brake specific fuel consumption at different load at different compression ratio as input. Emission parameters as carbon mono oxide un burnt hydrocarbon, carbon di-oxide, oxygen and oxides of nitrogen was also determined. A productive examination of the procedure and positioning of choices can be accomplished for enhancement blends choice through TOPSIS and VIKOR techniques. Starting with normalized and weighted normalized decision matrix, positive and negative ideal solution, the distance of alternative from positive and negative ideal solution was calculated and closeness coefficient of alternative in the form of ranking of alternative was done. It was found that a mix B75 was the most appropriate blend for Karanja biodiesel for best use in CI engine without influencing the emission and performance parameters.
\end{abstract}

Keywords : Biodiesel, Diesel Engine, TOPSIS, VIKOR..

\section{INTRODUCTION}

Compression ignition (CI) engine plays an important role in many fields including automobiles, marine propulsion, industrial, domestic needs [1]. With increasing demand of transportation and population, the demand for energy is also increasing. For both developed and growing economies, the demand for energy is also growing rapidly [2-4]. Efforts are on top to discover the alternative sources of energy to fulfil

Revised Manuscript Received on June 15, 2020.

* Correspondence Author

Mukul Agarwal*, Department of Mechanical Engineering, Meerut Institute of Engineering \& Technology, Meerut (UP), India.

Shailendra Kumar, (Dr. A.P.J .Abdul Kalam Technical University, Lucknow, Uttar Pradesh, India.

(C) The Authors. Published by Blue Eyes Intelligence Engineering and Sciences Publication (BEIESP). This is an open access article under the CC BY-NC-ND license (http://creativecommons.org/licenses/by-nc-nd/4.0/) the demand of it for the future generation. It is estimated that by the year 2035, $0.7 \%$ per capita, consumption of energy will also increase [5-7]. In the meantime, several studies have revealed that the growing consumption of fossil fuel will lead to the exhaustion of crude oil reserves somewhere between 2050 and 2075 [6, 8]. Therefore, there is a pressing need to replace the energy supply system of fossil fuel fully or at least partly with the other renewable alternative fuel. The alternative fuels/ Bio-fuels are one of renewable source to fulfil the world energy demand [9, 10]. Bio-fuel is the plausible alternative for fossil fuels as it is less pollutant, renewable, and having similar properties to diesel fuel. It also reduces the greenhouse gas emission and environmental disaster comparative to crude oil which leaves massive carbon footprints [6]. World-wide researchers are exploring hard in search of alternative fuels for diesel engines. Without making any physical change in existing diesel engines, different kind of biodiesels and their blends are tested as an alternative fuel for it. The American Society for Testing and Material (ASTM) characterizes that biodiesel can be created by the mono-alkyl esters of long-chain fatty acids derived from the sustainable lipid feedstock, including creature oil, vegetable oil, waste oil, and so forth [11-12]. The development of yields for biodiesel production form food grains poses a threat to food security and also contributes to a decline in soil richness [13]. Though utilization of the biodiesel in CI engine can decrease the hydrocarbon (HC), carbon monoxides (CO) and smoke emission, it will also increase the oxides of nitrogen (NOX), because of $10 \%$ content of oxygen $\left(\mathrm{O}_{2}\right)$ present in biodiesel that causes $\mathrm{NO}_{\mathrm{X}}$ formation. These are few disadvantages of biodiesel, such as higher atomic weight, high viscosity, low volatility, high pour point contrasted to diesel. This leads to incomplete combustion and responsible poor atomization [14, 15]. Numerous researchers and specialists examined several biodiesel and its blends. In a study, Sahoo et. al. [2] investigated Karanja, Polanga and Jatropha based biodiesel and their 20 and 50\% (by vol.) blends were considered at different loads (0, 50 and 100\%) and reported that Pongamia oil blended with 50\% (B50 blend) diesel gave the maximum power output. Bajpai et al. [15] tested different blends of Karanja Oil (KO) and diesel fuel (5\%, 10\%, 15\% and 20\%) in a single cylinder direct injection (DI), CI engine at different loads $(0 \%, 20 \%, 40 \%, 60 \%, 80 \%$, and $100 \%)$ and constant speed. Highest BTE is observed for $10 \% \mathrm{KO}$ blend at $60 \%$ load. 
The review of relevant literature clearly indicates that the researchers are working sincerely to discover the appropriate option of diesel without any physical modifications in the existing diesel engine.

In brief, different input parameters including load, compression ratio (CR), a blend of fuels are varied and the performance and emission characteristics of the engine are observed. It is observed that multiple performance parameters were studied under number of diverse frameworks. There is a need for a systematic approach to ascertain the number of experiments in order to cover the entire domain of input parameters.

In the present study, Karanja oil methyl ester as biodiesel is chosen to examine the better engine performance along with minimum exhaust emission characteristics by implementing TOPSIS (technique for order performance by similarity to ideal solution) and VIKOR (Visekriterijimsko Kompromisno Rangiranje) approach is proposed as a hybrid of Multi-Criteria Decision Making (MCDM) techniques for assessing and choosing the optimal fuel blends for CI engine.

Remaining portion of paper is divided into seven sections. Section 2 explain the literature review, section 3 provided the methodology of MCDM techniques followed in VIKOR and TOPSIS method. Section 4 describes the method for the selection of the best blend. The experimental procedure adopted is explained in section 5 . Results are explained in section 6 and finally section 7 gives the conclusion the paper.

\section{LITERATURE REVIEW}

MCDM is a part of operational research shows managing choice issue under the nearness of factor and criteria. It gives advanced technique sensible instruments that are arranged towards the help of the leader in confronting complex genuine choice [16]. MCDM techniques applied in automobile sector have been used in the previous couple of decades. A few application regions connected by Maheswari al. [17] used nonlinear regression analysis on $13 \%$ blend of biodiesel with the $24^{\circ}$ bTDC injection timing. Shi et al. [18] proposed, NSGA (non dominated sorting genetic algorithm) for solving the minimum value of NOx emission and BSFC on single cylinder SI (spark ignition) engine. Josc et al. [19] applied a MOPSO (multi objective particle swarm optimization) and NSGA method for reduction of emission on SI engine. Some other experiments are presented in table [1].

\begin{tabular}{|c|c|c|c|}
\hline \multicolumn{4}{|c|}{ Table- I: Review } \\
\hline Author & Technigues & Application & Study reason \\
\hline $\begin{array}{l}\text { Chen } \\
\text { zheng } \\
\text { et.all } 20 \text { l }\end{array}$ & $\begin{array}{l}\text { ANN } \\
\text { Minitab } \\
\text { software }\end{array}$ & $\begin{array}{l}\text { Perfomance } \\
\text { and emission }\end{array}$ & $\begin{array}{l}\text { Analyzed of dissel } \\
\text { engine paraneters }\end{array}$ \\
\hline $\begin{array}{l}W_{2 n} \\
{[21]}\end{array}$ & $\begin{array}{l}\text { Taguchi } \\
\text { method by } \\
\text { Minitab }\end{array}$ & Injection yystem & $\begin{array}{l}\text { Anolysed diest } \\
\text { engine poromete } \\
\text { likenoise, emission }\end{array}$ \\
\hline $\begin{array}{l}\text { Ganapathy } \\
\text { et.al [22] }\end{array}$ & $\begin{array}{l}\text { Taguchi } \\
\text { method }\end{array}$ & Injection tinging & $\begin{array}{l}\text { Select } \\
\text { perfomance and } \\
\text { enission } \\
\text { Jatropha Biodiesel }\end{array}$ \\
\hline $\begin{array}{l}\text { Tijaykumar } \\
\text { et.al [23] }\end{array}$ & $\begin{array}{l}\text { Evabation of } \\
\text { numerical } \\
\text { model }\end{array}$ & $\begin{array}{l}\text { Perfomance } \\
\text { and emission }\end{array}$ & $\begin{array}{l}\text { Perfomance and } \\
\text { omission of biofulled } \\
\text { IC engune }\end{array}$ \\
\hline $\begin{array}{l}\text { Pandian } \\
\text { et.al }[24]\end{array}$ & $\begin{array}{l}\text { Response } \\
\text { surface } \\
\text { methodobgy }\end{array}$ & $\begin{array}{l}\text { Effect of } \\
\text { injection system }\end{array}$ & $\begin{array}{l}\text { Select the blend of } \\
\text { Pongania biodiesel }\end{array}$ \\
\hline $\begin{array}{l}\text { Bharathingj } \\
\text { a etal [25] }\end{array}$ & $\begin{array}{l}\text { Lab view } \\
\text { software }\end{array}$ & $\begin{array}{l}\text { Perfomance } \\
\text { and emission }\end{array}$ & $\begin{array}{l}\text { Characteristics of } \\
\text { ethanol fumigation }\end{array}$ \\
\hline $\begin{array}{l}\text { Balafoutis } \\
\text { et al }[26]\end{array}$ & $\begin{array}{l}\text { AHP } \\
\text { TOPSIS }\end{array}$ & Injection tining & $\begin{array}{l}\text { Select the best blend } \\
\text { of unnflower oil }\end{array}$ \\
\hline $\begin{array}{l}\text { Sakthinel et } \\
\text { al. }[27]\end{array}$ & $\begin{array}{l}\text { GRA } \\
\text { TOPSIS }\end{array}$ & $\begin{array}{l}\text { Different } \quad b a d \\
\text { condition }\end{array}$ & $\begin{array}{l}\text { Selection of best } \\
\text { blend offish oil }\end{array}$ \\
\hline $\begin{array}{ll}\text { Akbari } \\
\text { al. }[28\}\end{array}$ & $\begin{array}{l}\text { Genetic } \\
\text { algonition }\end{array}$ & Production & $\begin{array}{l}\text { Prodiction } \\
\text { biodiesel }\end{array}$ \\
\hline $\begin{array}{l}\text { Etghani et } \\
\text { al. [29] }\end{array}$ & $A N N$ & Direct injection & $\begin{array}{l}\text { Perfomance of } \\
\text { castor oil biodiesel }\end{array}$ \\
\hline $\begin{array}{lll}\text { Liu } & \text { et al. } \\
{[30]} & & \end{array}$ & $\begin{array}{l}\text { Genetic } \\
\text { algonition }\end{array}$ & Optimixation & $\begin{array}{l}\text { NOx conversion } \\
\text { efficiency }\end{array}$ \\
\hline $\begin{array}{l}\text { Gaikwad et } \\
\text { al. }[31]\end{array}$ & $\begin{array}{l}\text { ANP, TOPSIS } \\
\text { \& VIKOR }\end{array}$ & Direct injection & Best sustable blend \\
\hline $\begin{array}{l}\text { Mohammad } \\
\text { harani et } \\
\text { al. [32] }\end{array}$ & $A N W$ & Enission & $\begin{array}{l}\text { Redice } \\
\text { emission }\end{array}$ \\
\hline $\begin{array}{l}\text { Lotfan et al. } \\
{[33]}\end{array}$ & $A N N$ & $\begin{array}{l}\text { Modelling } \\
\text { analyse }\end{array}$ & $\begin{array}{l}\text { Redice } \mathrm{CO} \mathrm{NOx} \\
\text { onission from deal } \\
\text { fisel enomes. }\end{array}$ \\
\hline
\end{tabular}

From the literature review, it can be found out a large amount of work has been done by to improve the performance and emission characteristics of biodiesel by using different MCDM techniques. Hence, the main objective of this present paper proposed a MCDM technique for determine the optimum blend. In this paper, discuss the two MCDM techniques, i.e. TOPSIS \& VIKOR are used to evaluating the best blend and this technique can be solved by Excel software sheet.

\section{METHODOLOGY}

In order to fulfil the requirement of data can be adopted from the paper "Optimization of Performance and Emission characteristics of a diesel engine with biodiesel [34]. In CI engine, performance and emission characteristics of Karanja biodiesel and diesel based on the three essential issues to be explicit, a blend of fuel, load and compression ratio were considered. Division of each factor is given in five levels as shown in table (2). Brake power (BP), Brake specific fuel (BSFC), and Brake thermal efficiency (BTE) are the three factors come out from the characteristics of engine performance. 
Remaining five factors come out from the characteristics of engine emission such as, $\mathrm{CO}, \mathrm{CO}_{2}, \mathrm{NO}_{\mathrm{X}}, \mathrm{HC}$ and $\mathrm{O}_{2}$. ASTM tested the properties of Diesel and Karanja biodiesel are presented in table (3).

Table 2: Factors and Levels of the engine*

\begin{tabular}{||l|l|l|l|l|l|}
\hline \multirow{2}{*}{ Design Factor } & \multicolumn{5}{|c|}{ Levels } \\
\cline { 2 - 6 } & \multicolumn{1}{|c|}{$\mathbf{2}$} & \multicolumn{1}{|c|}{$\mathbf{3}$} & $\mathbf{4}$ & $\mathbf{5}$ \\
\hline Load in Kg & 4 & 8 & 12 & 16 & 20 \\
\hline Blend & B0 & B25 & B50 & B75 & B100 \\
\hline $\begin{array}{l}\text { Compression } \\
\text { Ratio }\end{array}$ & $14: 1$ & $15: 1$ & $16: 1$ & $17: 1$ & $18: 1$ \\
\hline
\end{tabular}

*[adopted from ref.34]

Table 3: Property of fuel*

\begin{tabular}{|c|c|c|c|}
\hline Property & Diesel & $\begin{array}{c}\text { Karanja } \\
\text { Biodiesel }\end{array}$ & $\begin{array}{c}\text { ASTM } \\
\text { standard }\end{array}$ \\
\hline $\begin{array}{l}\text { Specific } \\
\text { Gravity }\end{array}$ & 0.824 & 0.880 & D3142-05 \\
\hline $\begin{array}{l}\text { Density } \\
\text { (gm/cc) }\end{array}$ & 0.717 & 0.766 & D1298 \\
\hline API Gravity & 40.24 & 29.3 & D4052 \\
\hline $\begin{array}{c}\text { Ash content } \\
(\%)\end{array}$ & 0.060 & 0.094 & D874 \\
\hline Cetane No. & 48 & 56.61 & D613 \\
\hline Viscosity (cSt) & 4.2 & 32.3 & D 2171 \\
\hline $\begin{array}{c}\text { Calorific Value } \\
\text { (kcal/kg) }\end{array}$ & 10056.2 & 8095.24 & D 5453-93 \\
\hline $\begin{array}{c}\text { Pour Point }\left({ }^{\circ} \mathrm{C}\right. \\
)\end{array}$ & 15 & 4 & D 5949 \\
\hline $\begin{array}{c}\text { Flash Point }\left({ }^{\circ} \mathrm{C}\right. \\
)\end{array}$ & 66 & 190 & D 6450 \\
\hline Fire Point $\left({ }^{\circ} \mathrm{C}\right)$ & 72 & 395 & D3828 \\
\hline $\begin{array}{c}\text { Carbon } \\
\text { Residue (\%) }\end{array}$ & 0.080 & 0.530 & D 189 \\
\hline $\begin{array}{c}\text { Water Content } \\
(\%)\end{array}$ & 0.07 & 1.66 & D 2709 \\
\hline Ash content & 0.060 & 0.094 & D874 \\
\hline
\end{tabular}

*[adopted from ref.34]

\section{A. TOPSIS Method}

This technique was discovered by Hwany and Yoon in 1981. Main objective of this technique, proved that the best method for selecting the best alternative blends and addressing the rank priority. By TOPSIS method, to obtain the solution of closest and farthest from ideal and non ideal solution [35, 36, and 37]

Step 1: By the help of the equation to calculate the normalization of decision matrix:

$$
\bar{X}_{i j}=\frac{X_{i j}}{\sqrt{\sum_{i=1}^{n} X_{i j}^{2}}}
$$$$
\mathrm{i}=1,2,3 \ldots \mathrm{n}
$$

Step 2: Constructed the weighted normalized matrix: In normalized decision matrix can be multiplied by associate weight $\mathrm{Wi}$ and to get results:

$$
V_{i j}=X_{i j} * W_{i}
$$

$$
\begin{aligned}
& j=1,2,3 \ldots n, \\
& i=1,2,3 \ldots n
\end{aligned}
$$

Step 3: Calculate the ideal solution of most $\mathrm{Ai}^{*}$ and least $\mathrm{Ai}$ - preferable alternative:

$\left.\mathrm{Ai}^{*}=\left\{\mathrm{v} 1^{*} \ldots \mathrm{vi} \mathbf{i}^{*}\right\}=\left\{\left(\max \mathrm{vij} \mid \mathrm{i} \in \mathrm{I}^{\prime}\right)\right\},\left(\min \mathrm{vij} \mid \mathrm{i} \in \mathrm{I} \mathrm{I}^{\prime}\right)\right\}$ (3)

$\mathrm{Ai}^{-}=\{\mathrm{v} 1-, \ldots . \mathrm{vi}-\}=\left\{\left(\min v \mathrm{vij} \mid \mathrm{i} \in \mathrm{I}^{\prime}\right)\right\},\left(\max\right.$ vij $\left.\left.\mid \mathrm{i} \in \mathrm{I}^{\prime \prime}\right)\right\}$

Step 4: By the help of n-criteria Euclidean distance equation to calculated the separation measurement of each alternatives:

$$
D_{i}^{+}=\left[\sum_{j=1}^{n}\left(V_{i j}-V_{j}^{+}\right)^{2}\right]^{0.5} \quad \mathrm{j}=1,2,3 \ldots \mathrm{n}
$$

$$
D_{i}^{-}=\left[\sum_{j=1}^{n}\left(V_{i j}-V_{j}^{-}\right)^{2}\right]^{0.5} \quad \mathrm{j}=1,2,3 \ldots \mathrm{n}
$$

Step 5: Determined the relative closeness of each alternative:

$$
C C_{j}=\frac{D_{i}^{-}}{D_{i}^{+}+D_{i}^{-}}
$$

Step 6: Rank preference: arrangement of alternatives in decreasing order of CCj.

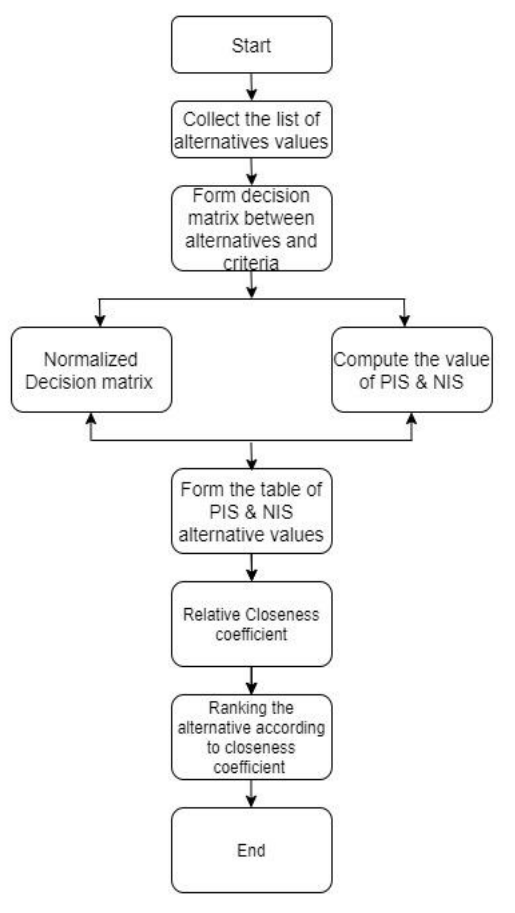

Fig 1: TOPSIS flow chart

Published By:

Blue Eyes Intelligence Engineering \& Sciences Publication 


\section{Selection of Karanja Biodiesel Blend for Engine Performance by using TOPSIS and VIKOR Method}

\section{B. VIKOR Method}

This method is created by Opricovic (1998) to solve the problem with commensurable and conflicting criteria. The main focused of this method to selecting and rank priority for best alternatives with commensurable and conflicting criteria [35, 37].

Step 1: Unify the normalized decision matrix for alternatives $\mathrm{X}_{\mathrm{ij}}$

$$
r_{i j}=\frac{X_{i j}}{\sqrt{\sum_{i=1}^{n} X_{i j}^{2}}} \quad \begin{aligned}
& \mathrm{j}=1,2,3 \ldots \mathrm{n}, \\
& \mathrm{i}=1,2,3 \ldots \ldots \mathrm{n}
\end{aligned}
$$

Step 2: calculated the best (fi*) and worst (fi-) values for every n-criteria function by this equation:

$$
\mathrm{fi}^{*}=\max _{\mathrm{j}} \mathrm{f}_{\mathrm{ij}}, \quad \mathrm{fi}-=\min _{\mathrm{j}} \mathrm{f}_{\mathrm{ij}} \quad \mathrm{j}=1,2,3, \ldots \mathrm{n}
$$

Step 3: For each alternatives to calculate the utility Si and $\mathrm{Ri}$ regret value from this equation (10) \& (11).

$$
\begin{aligned}
& S_{i}=\left[\sum_{i=1}^{m} w_{i}\left(f *_{i}-f_{i j}\right) /\left(f *_{i}-f_{i}^{-}\right)\right] \\
& R_{i}=\max \left[w_{i}\left(f *_{i}-f_{i j}\right) /\left(f *_{i}-f_{i}^{-}\right)\right]
\end{aligned}
$$

where $\mathrm{w}_{\mathrm{i}}$ represent the weight of the ith criterion.

Step 4: Determined the value of VIKOR index:

$\mathrm{Q}_{\mathrm{i}}=\mathrm{v}\left(\mathrm{S}_{\mathrm{i}}-\mathrm{S}^{*}\right) /\left(\mathrm{S}^{-}-\mathrm{S}^{*}\right)+(1-\mathrm{v})\left(\mathrm{R}_{\mathrm{i}}-\mathrm{R}^{*}\right) /\left(\mathrm{R}^{-}-\mathrm{R}_{\mathrm{i}}\right)$

Where $\mathrm{S}^{*}=\operatorname{mini} \mathrm{S}_{\mathrm{i}}, \mathrm{R}^{*}=\operatorname{mini} \mathrm{R}_{\mathrm{i}}, \mathrm{R}^{-}=\operatorname{maxi} \mathrm{Rand} \mathrm{v}$ is represented as weight of the strategy of the majority of criteria, here $\mathrm{v}=0.5$.

\section{Step 5: Rank priority:}

Select the smallest value of best alternative value by VIKOR method. A' is the compromise solution for alternative. Rank priority followed by two satisfies condition:

C1 Acceptable advantage: $Q\left(A^{\prime \prime}\right)-Q\left(A^{\prime}\right) \geq D Q$

Where $A$ " represent the second position of alternative in the ranking list by $\mathrm{Q}, \mathrm{DQ}=1 / \mathrm{m}-1)$; $\mathrm{m}$ represent the number of alternatives.

C2 Acceptable stability: Alternative $A^{\prime}$ represent the best ranked of alternative by $\mathrm{R}$ and $\mathrm{S}$. According to decisionmaking process, compromise solution is stable with "voting by majority rule" $\mathrm{v} \approx 0.5$, or with veto $(\mathrm{v}<0.5)$. Here, $\mathrm{v}$ represents the strategy of weighted decision making. According to compromise solution, if one condition is not satisfied which consist is:

- $\mathrm{A}^{\prime}, \mathrm{A}$ "...., AN alternatives, if $\mathrm{C} 1$ condition is not satisfied; AN give the relation $\mathrm{Q}(\mathrm{AN})-\mathrm{Q}\left(\mathrm{A}^{\prime}\right)<\mathrm{DQ}$ for maximum $\mathrm{N}$, or

- $\mathrm{A}^{\prime}$ and $\mathrm{A}$ " an alternative, only $\mathrm{C} 2$ condition not satisfied.

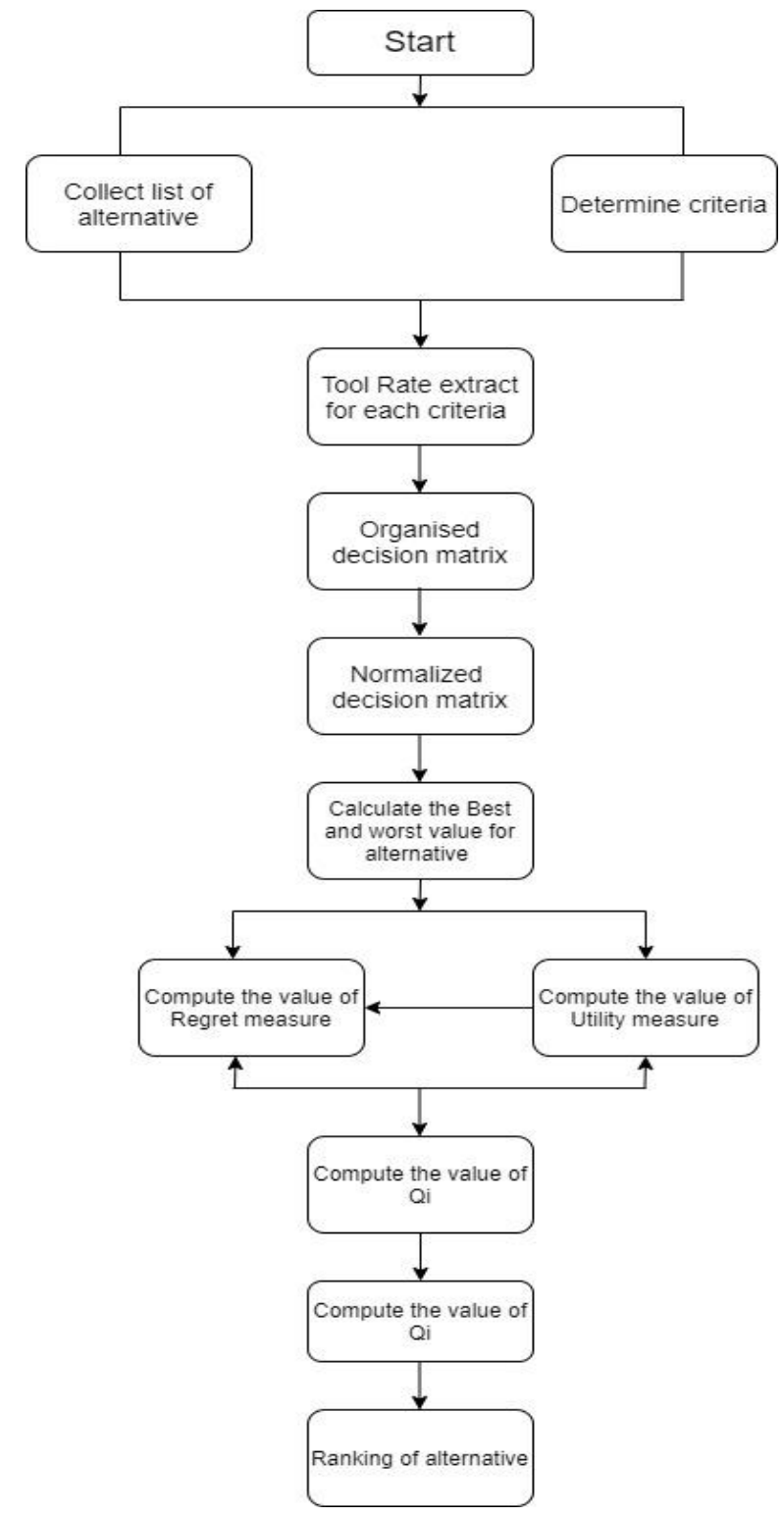

Fig 2: Flow chart of Vikor Method

\section{METHOD FOR SELECTING A BEST BLEND}

In this investigation, the specialists have utilized the writing study to recognize the assessment criteria for the chose of the best blend (4). The criteria are organized in a progressive structure as appeared in fig (3). The collective choice-making strategies allow incorporating the suppositions of various IC engine assembling and motor specialists in the basic leadership process. The distinguished criteria are portrayed beneath [35]:

1. NOx: Formation of nitrogen oxides in engine due to ignition delay, flame temperature and the substance of nitrogen and oxygen available in the reaction mixture.

2. Smoke: Molecular structure of the biodiesel, smoke emission depends on the content of oxygen due to the thermal cracking process; smoke emission is generated with long-chain

of HC molecules in an oxygen incomplete combustion environment.

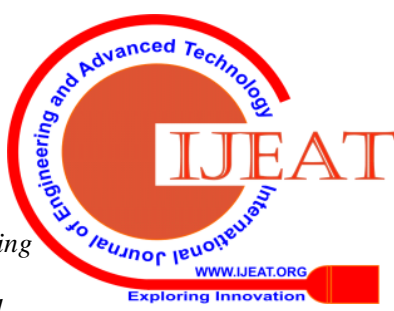


3. Brake Thermal Efficiency: Thermal input of the fuel is the main function of the engine can describe the brake power. BTE shows that evaluate how efficient the energy of fuel converted into mechanical energy.

4. $\mathrm{CO}_{2}$ : The burning efficiency of fuel inside the combustion chamber is indicated by the $\mathrm{CO}_{2}$ emission of diesel engine. Most of the conversion of carbon into carbon dioxides shows good combustion.

5. CO: CO emission depends on the matter of oxygen, carbon and the ability of combustion fuel to form

$\mathrm{CO}$, present of carbon in the fuel is oxidized with oxygen present in the air and to form CO.

6. Hydrocarbon (HC): In the presence of oxygen, take part of hydrocarbon in combustion reaction and remaining part of hydrocarbon comes out in form of unburned HC.

7. Exhaust gas temperature: After the combustion in cylinder, the mixing of the fuel at accurate temperature. It is important parameters to analyze the emission values and indicates combustion efficiency.

8. Ignition delay: It is the difference between the time interval of injection and combustion process start in the diesel engine. Ignition delay can be created by vaporization, atomization, mixing of fuel in air and the reaction due pre-combustion.

9. Combustion duration: Combustion duration can determine the heat release data by the whole process of combustion from starting point to ending point.

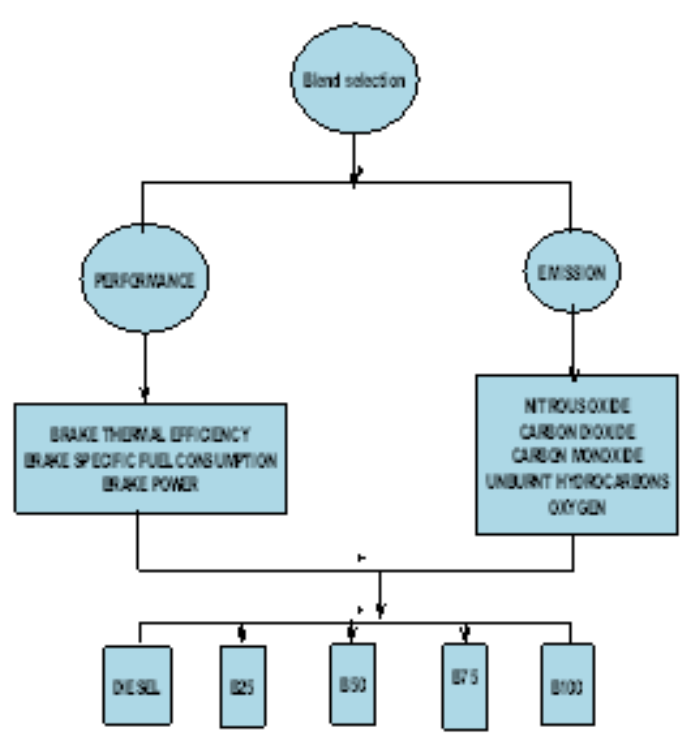

Fig 3: Decision hierarchy

\section{EXPERIMENTAL PROCEDURE}

\section{A.TOPSIS computations}

The proposed of this TOPSIS technique for selects the best alternative blend. Consideration emission and performance characteristics of engine at $20 \%$ load at 14 CR and apply the TOPSIS method. In TOPSIS method, firstly to calculated the normalized matrix on experimental reading of emission and engine performance at $14,15,16,17$ and $18 \mathrm{CR}$ using the equation (1) from table (4). After the calculation normalized decision matrix reading are put in table (5). Considering the weighted criteria and to compute in weighted normalized decision matrix by using the equation (2) and represent in table (6).

After the matrix of weighted normalized is formed ideal and non ideal solution for alternative by using the equation (3-4) and tabulated in table form (7-8).

$$
\begin{aligned}
& A^{*}=\{0.020,0.018,0.019,0.018,0.038\}=\{0.020\} \\
& A^{-}=\{0.020,0.018,0.019,0.018,0.038\}=\{0.018\}
\end{aligned}
$$

Then also compute the each criterion by using the equation (5-6) to determine the value of alternative distance from ideal and non ideal solution and tabulate in (9-10).

$$
\begin{aligned}
& \mathrm{Di}^{*}=\left[(0.020-0.020)^{\wedge} 2+(0.1002-0.0754)^{\wedge} 2+(0.0281-\right. \\
& 0.0422)^{\wedge}+(0.003-0.0006)^{\wedge} 2+(0.0029-0.0006)^{\wedge} 2+ \\
& (0.0038-0.0030)^{\wedge}+(0.0023-0.0023)^{\wedge} 2+(0.0010- \\
& \left.0.0009)^{\wedge}\right]^{\wedge} 0.5=0.029 \\
& \mathrm{Di}-=\left[(0.020-0.0186)^{\wedge} 2+(0.1002-0.1009)^{\wedge} 2+(0.0281-\right. \\
& 0.0281)^{\wedge}+(0.003-0.0034)^{\wedge}+(0.0029-0.0036)^{\wedge} 2+ \\
& (0.0038-0.0038)^{\wedge} 2+(0.0023-0.005)^{\wedge} 2+(0.0010- \\
& \left.0.0049)^{\wedge}\right]^{\wedge} 0.5=0.004
\end{aligned}
$$

Then find the coefficient of closeness for each alternative with respect to positive and negative ideal solution by apply the equation (7). Lastly, calculate the rank priority of every closeness coefficient alternatives.

$$
\begin{gathered}
\mathrm{CC} 1 *=0.126 \quad \mathrm{CC} 2 *=0.142 \quad \mathrm{CC}^{*} *=0.744 \\
\mathrm{CC}^{*} *=0.921 \quad \mathrm{CC}^{*} *=0.345
\end{gathered}
$$

Similarly the procedure is followed for selecting the best alternative blend value at $40 \%, 60 \%, 80 \%$, and $100 \%$ load. Results and rank of every alternative of closeness coefficient are presented in tabulated (11).

\section{B. VIKOR computations}

Utilization of this VIKOR technique for selects the best alternative blend. Performance and emission characteristics of engine at $20 \%$ load at $14 \mathrm{CR}$ are considered to demonstrate the computational procedure for VIKOR method:

Step 1: In VIKOR method, to calculate the normalized decision matrix by help of TOPSIS table (5).

Step 2: After the calculation of normalized matrix, to calculate the best $\mathrm{f}^{*}$ and worst $\mathrm{fi}^{-}$value by using the equation (9).

$$
\begin{aligned}
& \mathrm{f}^{*}=\{0.0668,0.0621,0.065,0.0650,0.062\}=\{0.0668\} \\
& \mathrm{f}^{-}=\{0.0668,0.0621,0.065,0.0650,0.062\}=\{0.0621\}
\end{aligned}
$$

Step 3: Calculate the value of $\mathrm{Si}$ and $\mathrm{Ri}$ by the equation (10-11). And obtained the results are tabulated (12-13).

Step 4: By equation (12) to calculate the value of VIKOR index and results outcomes are given in table (14).

Step 5: Calculate the smallest index value to select the best blend. 


\begin{tabular}{|c|c|c|c|c|c|c|c|c|c|c|c|}
\hline & \multicolumn{11}{|c|}{ T able 4: Experimental value* } \\
\hline \multicolumn{12}{|c|}{$\begin{array}{l}\text { Experi } \\
\text { ment }\end{array}$} \\
\hline 1 & \multirow{5}{*}{20} & 0 & 14 & 1.223 & 632.784 & 13.521 & 0.35 & 58 & 4.8 & 14.2 & 117 \\
\hline 2 & & 25 & 15 & 1.138 & 624.431 & 14.207 & 0.36 & 70 & 4 & 15.03 & 105 \\
\hline 3 & & 50 & 16 & 1.2 & 509.584 & 18.029 & 0.17 & 43 & 3.8 & 15.53 & 218 \\
\hline 4 & & 75 & 17 & 1.19 & 474.778 & 20.317 & 0.08 & 17 & 4 & 15.45 & 400 \\
\hline 5 & & 100 & 18 & 1.15 & 599.332 & 17.734 & 0.06 & 11 & 4.2 & 15.36 & 596 \\
\hline 6 & \multirow{5}{*}{40} & 0 & 15 & 2.33 & 365.421 & 23.414 & 0.06 & 25 & 5.6 & 13.64 & 702 \\
\hline 7 & & 25 & 16 & 2.26 & 362.915 & 24.445 & 0.07 & 41 & 5.6 & 13.33 & 726 \\
\hline 8 & & 50 & 17 & 2.25 & 345.877 & 26.562 & 0.04 & 37 & 5.4 & 13.71 & 843 \\
\hline 9 & & 75 & 18 & 2.342 & 337.708 & 28.564 & 0.05 & 13 & 6 & 13.51 & 963 \\
\hline 10 & & 100 & 14 & 2.442 & 399.555 & 26.601 & 0.21 & 23 & 5.8 & 13.3 & 247 \\
\hline 11 & \multirow{5}{*}{60} & 0 & 16 & 3.403 & 271.75 & 31.485 & 0.01 & 22 & 7.3 & 11.42 & 1154 \\
\hline 12 & & 25 & 17 & 3.351 & 293.691 & 30.207 & 0.02 & 31 & 7.4 & 11.28 & 1316 \\
\hline 13 & & 50 & 18 & 3.475 & 271.973 & 33.78 & 0.02 & 39 & 7.2 & 11.5 & 1130 \\
\hline 14 & & 75 & 14 & 3.282 & 327.154 & 29.485 & 0.1 & 32 & 7.8 & 10.86 & 859 \\
\hline 15 & & 100 & 15 & 3.431 & 317.996 & 33.424 & 0.07 & 18 & 7.3 & 11.62 & 983 \\
\hline 16 & \multirow{5}{*}{80} & 0 & 17 & 4.469 & 255.027 & 33.55 & 0.02 & 7 & 1.1 & 19.25 & 123 \\
\hline 17 & & 25 & 18 & 4.497 & 255.32 & 34.747 & 0.04 & 34 & 9.5 & 8.59 & 1240 \\
\hline 18 & & 50 & 14 & 4.319 & 283.192 & 32.442 & 0.08 & 55 & 9.6 & 8.6 & 1298 \\
\hline 19 & & 75 & 15 & 4.326 & 287.354 & 33.569 & 0.05 & 30 & 9.3 & 9.05 & 1337 \\
\hline 20 & & 100 & 16 & 4.412 & 299.319 & 35.51 & 0.05 & 21 & 9 & 9.57 & 1463 \\
\hline 21 & \multirow{5}{*}{100} & 0 & 18 & 5.272 & 277.365 & 30.848 & 0.32 & 16 & 4.5 & 14.69 & 482 \\
\hline 22 & & 25 & 14 & 5.57 & 284.662 & 31.165 & 0.73 & 84 & 11.6 & 5.29 & 1209 \\
\hline 23 & & 50 & 15 & 5.411 & 287.639 & 31.94 & 0.3 & 65 & 11.3 & 6.06 & 1350 \\
\hline 24 & & 75 & 16 & 5.281 & 299.598 & 32.197 & 0.17 & 39 & 11.2 & 6.57 & 1360 \\
\hline 25 & & 100 & 17 & 5.539 & 300.61 & 35.357 & 0.12 & 29 & 11.1 & 6.81 & 1410 \\
\hline & $\begin{array}{c}\text { Load } \\
\%\end{array}$ & Blend & $\mathrm{CR}_{\mathrm{R}}$ & $\begin{array}{c}\mathrm{BP} \\
(\mathrm{Kw})\end{array}$ & $\begin{array}{c}\text { BSFC } \\
(\mathrm{gm} / \mathrm{Kwhr})\end{array}$ & BTE & $\begin{array}{c}\mathrm{CO} \\
(\% \mathrm{ol})\end{array}$ & $\begin{array}{c}\mathrm{HC} \\
(\mathrm{ppm} / \mathrm{v} \\
\mathrm{oI})\end{array}$ & $\begin{array}{c}\mathrm{CO}_{2} \\
(\% \circ \mathrm{ol})\end{array}$ & $\begin{array}{c}\mathrm{O}_{2} \\
(\% \text { ol })\end{array}$ & $\begin{array}{c}\mathrm{NOx} \\
(\mathrm{ppm} / \mathrm{vol})\end{array}$ \\
\hline
\end{tabular}

\begin{tabular}{|c|c|c|c|c|c|c|c|c|c|}
\hline \multirow{2}{*}{ Load } & \multicolumn{9}{|c|}{ Table 5: Normalized decision matrix } \\
\hline & Blend & $\begin{array}{c}B P \\
(K w)\end{array}$ & $\begin{array}{c}\text { BSFC } \\
(g n / K \text { whr })\end{array}$ & $B I E$ & $\begin{array}{c}\mathrm{CO} \\
(\% \text { vol })\end{array}$ & $\begin{array}{c}H C \\
(p p m / 1 o l)\end{array}$ & $\begin{array}{c}\mathrm{CO}_{2} \\
(\% \text { vol })\end{array}$ & $\begin{array}{c}\mathrm{O}_{2} \\
(\% \mathrm{vol})\end{array}$ & $\begin{array}{c}\text { Nox } \\
(p p m / i v o l)\end{array}$ \\
\hline \multirow{5}{*}{20} & B0 & 0.067 & 0.336 & 0.094 & 0.327 & 0.295 & 0.128 & 0.232 & 0.024 \\
\hline & B25 & 0.062 & 0.332 & 0.098 & 0.336 & 0.356 & 0.107 & 0.245 & 0.021 \\
\hline & B50 & 0.066 & 0.271 & 0.125 & 0.159 & 0.219 & 0.101 & 0.253 & 0.045 \\
\hline & B75 & 0.065 & 0.252 & 0.141 & 0.075 & 0.086 & 0.107 & 0.252 & 0.082 \\
\hline & $\mathrm{B} 100$ & 0.063 & 0.319 & 0.123 & 0.056 & 0.056 & 0.112 & 0.251 & 0.122 \\
\hline \multirow{5}{*}{40} & B0 & 0.127 & 0.194 & 0.162 & 0.056 & 0.127 & 0.149 & 0.222 & 0.144 \\
\hline & B25 & 0.123 & 0.193 & 0.169 & 0.065 & 0.208 & 0.149 & 0.217 & 0.149 \\
\hline & B50 & 0.123 & 0.184 & 0.184 & 0.037 & 0.188 & 0.144 & 0.224 & 0.173 \\
\hline & B75 & 0.128 & 0.180 & 0.198 & 0.047 & 0.066 & 0.160 & 0.220 & 0.197 \\
\hline & B 100 & 0.133 & 0.212 & 0.184 & 0.196 & 0.117 & 0.155 & 0.217 & 0.051 \\
\hline \multirow{5}{*}{60} & B0 & 0.186 & 0.144 & 0.218 & 0.009 & 0.112 & 0.195 & 0.186 & 0.236 \\
\hline & B25 & 0.183 & 0.156 & 0.209 & 0.019 & 0.158 & 0.197 & 0.184 & 0.269 \\
\hline & B50 & 0.190 & 0.145 & 0.234 & 0.019 & 0.198 & 0.192 & 0.188 & 0.231 \\
\hline & B75 & 0.179 & 0.174 & 0.204 & 0.093 & 0.163 & 0.208 & 0.177 & 0.176 \\
\hline & B 100 & 0.187 & 0.169 & 0.231 & 0.065 & 0.092 & 0.195 & 0.190 & 0.201 \\
\hline \multirow{5}{*}{80} & B0 & 0.244 & 0.136 & 0.232 & 0.019 & 0.036 & 0.029 & 0.314 & 0.025 \\
\hline & B25 & 0.246 & 0.136 & 0.241 & 0.037 & 0.173 & 0.253 & 0.140 & 0.254 \\
\hline & B50 & 0.236 & 0.151 & 0.225 & 0.075 & 0.280 & 0.256 & 0.140 & 0.266 \\
\hline & B75 & 0.236 & 0.153 & 0.233 & 0.047 & 0.153 & 0.248 & 0.148 & 0.274 \\
\hline & B 100 & 0.241 & 0.159 & 0.246 & 0.047 & 0.107 & 0.240 & 0.156 & 0.299 \\
\hline \multirow{5}{*}{100} & B0 & 0.288 & 0.147 & 0.214 & 0.299 & 0.081 & 0.120 & 0.240 & 0.099 \\
\hline & B25 & 0.304 & 0.151 & 0.216 & 0.682 & 0.427 & 0.309 & 0.086 & 0.247 \\
\hline & B50 & 0.296 & 0.153 & 0.221 & 0.280 & 0.330 & 0.301 & 0.099 & 0.276 \\
\hline & B75 & 0.288 & 0.159 & 0.223 & 0.159 & 0.198 & 0.299 & 0.107 & 0.278 \\
\hline & B 100 & 0.303 & 0.160 & 0.245 & 0.112 & 0.147 & 0.296 & 0.111 & 0.289 \\
\hline
\end{tabular}

Retrieval Number: D8038049420/2020@BEIESP DOI: 10.35940/ijeat.D8038.069520 Journal Website: www.ijeat.org
Published By: Blue Eyes Intelligence Engineering \& Sciences Publication (C) Copyright: All rights reserved.

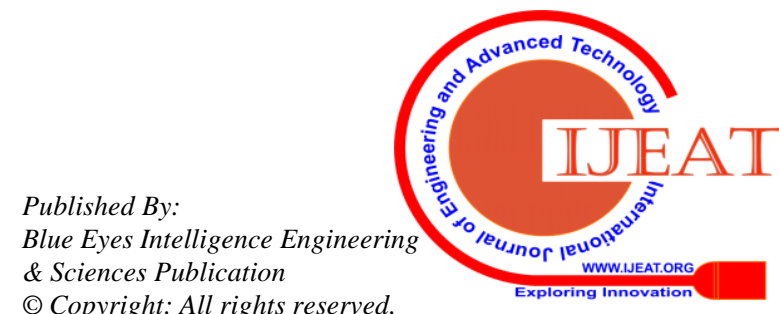




\begin{tabular}{|c|c|c|c|c|c|c|c|c|}
\hline \multicolumn{9}{|c|}{ Table 7: Positive ideal solution $A^{*}$} \\
\hline Blend & $\begin{array}{c}B P \\
(K w)\end{array}$ & $\begin{array}{c}B S F C \\
(g n / K w h r)\end{array}$ & BTE & $\begin{array}{c}C O \\
\text { (\%vol) }\end{array}$ & $\begin{array}{c}H C \\
\text { (ppintivol) }\end{array}$ & $\begin{array}{c}\mathrm{CO}_{2} \\
\text { (\%vol) }\end{array}$ & $\begin{array}{c}\mathrm{O}_{2} \\
(\% \text { wol })\end{array}$ & $\begin{array}{c}\text { NOx } \\
\text { (ppmivol) }\end{array}$ \\
\hline B0 & 0.0200 & 0.0757 & 0.0422 & 0.0006 & 0.0006 & 0.0030 & 0.0023 & 0.0009 \\
\hline B25 & 0.0400 & 0.0539 & 0.0594 & 0.0004 & 0.0007 & 0.0043 & 0.0022 & 0.0020 \\
\hline B50 & 0.0569 & 0.0433 & 0.0702 & 0.0001 & 0.0009 & 0.0058 & 0.0018 & 0.0070 \\
\hline B75 & 0.0737 & 0.0407 & 0.0738 & 0.0002 & 0.0004 & 0.0009 & 0.0014 & 0.0010 \\
\hline $\mathrm{Bl} 00$ & 0.0913 & 0.0442 & 0.0735 & 0.0011 & 0.0008 & 0.0036 & 0.0009 & 0.0039 \\
\hline
\end{tabular}

\begin{tabular}{|c|c|c|c|c|c|c|c|c|}
\hline \multicolumn{9}{|c|}{ Table 8: Negative ideal solution $A$ ? } \\
\hline Blend & $\begin{array}{c}B P \\
(K w)\end{array}$ & $\begin{array}{c}\text { BSFC } \\
(g n / K w h r)\end{array}$ & BTE & $\begin{array}{c}\mathrm{CO} \\
\text { (\%1ol) }\end{array}$ & $\begin{array}{c}H C \\
\text { (ppmivol) }\end{array}$ & $\begin{array}{c}\mathrm{CO}_{2} \\
\text { (\%vol) }\end{array}$ & $\begin{array}{c}\mathrm{O}_{2} \\
(\% \text { vol })\end{array}$ & $\begin{array}{c}\text { Nox } \\
\text { (ppmivol) }\end{array}$ \\
\hline $\mathrm{B} 0$ & 0.0186 & 0.1009 & 0.0281 & 0.0034 & 0.0036 & 0.0038 & 0.0025 & 0.0049 \\
\hline B25 & 0.0188 & 0.0637 & 0.0487 & 0.0020 & 0.0021 & 0.0048 & 0.0022 & 0.0079 \\
\hline B50 & 0.0569 & 0.0522 & 0.0613 & 0.0009 & 0.0020 & 0.0062 & 0.0019 & 0.0108 \\
\hline B75 & 0.0737 & 0.0477 & 0.0674 & 0.0007 & 0.0028 & 0.0077 & 0.0031 & 0.0120 \\
\hline $\mathrm{B} 100$ & 0.0864 & 0.0479 & 0.0641 & 0.0068 & 0.0043 & 0.0093 & 0.0024 & 0.0115 \\
\hline
\end{tabular}

\begin{tabular}{|c|c|c|c|c|c|c|c|c|c|}
\hline \multirow{2}{*}{ Load } & \multicolumn{9}{|c|}{ Table 6: Weighted normalized decision matrix } \\
\hline & Blend & $\begin{array}{c}B P \\
(K w)\end{array}$ & $\begin{array}{c}\text { BSFC } \\
(g m / K \text { ulur) }\end{array}$ & $B I E$ & $\begin{array}{c}\mathrm{CO} \\
(\% \mathrm{vol})\end{array}$ & $\begin{array}{c}H C \\
(p p m / i o l)\end{array}$ & $\begin{array}{c}\mathrm{CO}_{2} \\
\text { (\%1vl) }\end{array}$ & $\begin{array}{c}\mathrm{O}_{2} \\
\text { (\%ol) }\end{array}$ & $\begin{array}{c}\text { NOx } \\
(p p m / v o l)\end{array}$ \\
\hline \multirow{5}{*}{20} & $\mathrm{~B} 0$ & 0.020 & 0.101 & 0.028 & 0.003 & 0.003 & 0.004 & 0.002 & 0.001 \\
\hline & B25 & 0.019 & 0.100 & 0.030 & 0.003 & 0.004 & 0.003 & 0.002 & 0.001 \\
\hline & B50 & 0.020 & 0.081 & 0.037 & 0.002 & 0.002 & 0.003 & 0.003 & 0.002 \\
\hline & B75 & 0.020 & 0.076 & 0.042 & 0.001 & 0.001 & 0.003 & 0.003 & 0.003 \\
\hline & $\mathrm{B} 100$ & 0.019 & 0.096 & 0.037 & 0.001 & 0.001 & 0.003 & 0.003 & 0.005 \\
\hline \multirow{5}{*}{40} & B0 & 0.038 & 0.058 & 0.049 & 0.001 & 0.001 & 0.004 & 0.002 & 0.006 \\
\hline & B25 & 0.037 & 0.058 & 0.051 & 0.001 & 0.002 & 0.004 & 0.002 & 0.006 \\
\hline & B50 & 0.037 & 0.055 & 0.055 & 0.000 & 0.002 & 0.004 & 0.002 & 0.007 \\
\hline & B75 & 0.038 & 0.054 & 0.059 & 0.000 & 0.001 & 0.005 & 0.002 & 0.008 \\
\hline & $\mathrm{B} 100$ & 0.040 & 0.064 & 0.055 & 0.002 & 0.001 & 0.005 & 0.002 & 0.002 \\
\hline \multirow{5}{*}{60} & $\mathrm{~B} 0$ & 0.056 & 0.043 & 0.065 & 0.000 & 0.001 & 0.006 & 0.002 & 0.009 \\
\hline & B25 & 0.055 & 0.047 & 0.063 & 0.000 & 0.002 & 0.006 & 0.002 & 0.011 \\
\hline & B50 & 0.057 & 0.043 & 0.070 & 0.000 & 0.002 & 0.006 & 0.002 & 0.009 \\
\hline & B75 & 0.054 & 0.052 & 0.061 & 0.001 & 0.002 & 0.006 & 0.002 & 0.007 \\
\hline & $\mathrm{B} 100$ & 0.056 & 0.051 & 0.069 & 0.001 & 0.001 & 0.006 & 0.002 & 0.008 \\
\hline \multirow{5}{*}{80} & B0 & 0.073 & 0.041 & 0.070 & 0.000 & 0.000 & 0.001 & 0.003 & 0.001 \\
\hline & B25 & 0.074 & 0.041 & 0.072 & 0.000 & 0.002 & 0.008 & 0.001 & 0.010 \\
\hline & B50 & 0.071 & 0.045 & 0.067 & 0.001 & 0.003 & 0.008 & 0.001 & 0.011 \\
\hline & B75 & 0.071 & 0.046 & 0.070 & 0.000 & 0.002 & 0.007 & 0.001 & 0.011 \\
\hline & $\mathrm{B} 100$ & 0.072 & 0.048 & 0.074 & 0.000 & 0.001 & 0.007 & 0.002 & 0.012 \\
\hline \multirow{5}{*}{100} & B0 & 0.086 & 0.044 & 0.064 & 0.003 & 0.001 & 0.004 & 0.002 & 0.004 \\
\hline & B25 & 0.091 & 0.045 & 0.065 & 0.007 & 0.004 & 0.009 & 0.001 & 0.010 \\
\hline & B50 & 0.089 & 0.046 & 0.066 & 0.003 & 0.003 & 0.009 & 0.001 & 0.011 \\
\hline & B75 & 0.087 & 0.048 & 0.067 & 0.002 & 0.002 & 0.009 & 0.001 & 0.011 \\
\hline & $\mathrm{B} 100$ & 0.091 & 0.048 & 0.073 & 0.001 & 0.001 & 0.009 & 0.001 & 0.012 \\
\hline
\end{tabular}

Retrieval Number: D8038049420/2020@BEIESP DOI: 10.35940/ijeat.D8038.069520 Journal Website: www.ijeat.org
Published By:

Blue Eyes Intelligence Engineering \& Sciences Publication

(C) Copyright: All rights reserved.

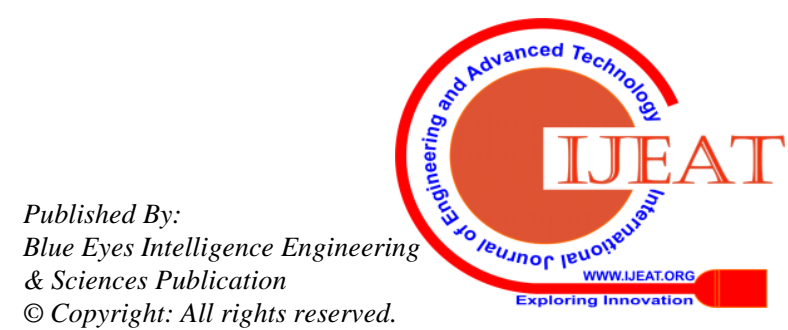


Selection of Karanja Biodiesel Blend for Engine Performance by using TOPSIS and VIKOR Method

\begin{tabular}{|c|c|c|c|c|c|c|c|c|c|c|}
\hline \multicolumn{11}{|c|}{ Table 14: Value of $Q_{i}$ at $v=0.5$} \\
\hline Blend & $\begin{array}{l}20 \% \\
\text { Load } \\
\end{array}$ & Rank & $\begin{array}{l}40 \% \\
\text { Load }\end{array}$ & Rank & $\begin{array}{l}60 \% \\
\text { Load } \\
\end{array}$ & Rank & $\begin{array}{l}80 \% \\
\text { Load } \\
\end{array}$ & Rank & $\begin{array}{l}100 \% \\
\text { Load }\end{array}$ & Rank \\
\hline B0 & 0.837 & 2 & 0.960 & 1 & 0.396 & 4 & 0.329 & 4 & 0.730 & 2 \\
\hline B25 & 1.000 & 1 & 0.946 & 2 & 0.730 & 2 & 0.000 & 5 & 0.411 & 4 \\
\hline B50 & 0.082 & 4 & 0.798 & 3 & 0.000 & 5 & 1.000 & 1 & 0.213 & 5 \\
\hline B75 & 0.039 & 5 & 0.000 & 5 & 1.000 & 1 & 0.903 & 2 & 0.938 & 1 \\
\hline $\mathrm{B} 100$ & 0.745 & 3 & 0.733 & 4 & 0.594 & 3 & 0.755 & 3 & 0.500 & 3 \\
\hline
\end{tabular}

*[adopted from ref.34]

\begin{tabular}{|c|c|c|c|c|c|}
\hline \multicolumn{7}{|c|}{ Table 9: Distance of a ltema tive from PIS $\mathrm{D}_{\mathrm{j}}{ }^{*}$} \\
\hline Blend & 20\%load & 40\%load & 60\%load & 80\%load & 100\%load \\
\hline B0 & 0.029 & 0.012 & 0.005 & 0.004 & 0.011 \\
\hline B25 & 0.027 & 0.011 & 0.009 & 0.012 & 0.014 \\
\hline B50 & 0.008 & 0.007 & 0.002 & 0.015 & 0.012 \\
\hline B75 & 0.003 & 0.006 & 0.013 & 0.014 & 0.013 \\
\hline B100 & 0.021 & 0.011 & 0.008 & 0.015 & 0.01 \\
\hline
\end{tabular}

\begin{tabular}{|c|c|c|c|c|c|c|c|c|c|c|}
\hline \multicolumn{11}{|c|}{ Table 11: Closeness coefficient $\left(\mathrm{CC}_{j}\right)$ and ranking of alternatives } \\
\hline Blend & $\begin{array}{l}20 \% \\
\text { Load } \\
\end{array}$ & Rank & $\begin{array}{l}40 \% \\
\text { Load } \\
\end{array}$ & Rank & $\begin{array}{l}60 \% \\
\text { Load } \\
\end{array}$ & Rank & $\begin{array}{l}80 \% \\
\text { Load }\end{array}$ & Rank & $\begin{array}{l}100 \% \\
\text { Load }\end{array}$ & Rank \\
\hline B0 & 0.126 & 5 & 0.622 & 5 & 0.646 & 2 & 0.772 & 1 & 0.513 & 2 \\
\hline $\mathrm{B} 25$ & 0.142 & 4 & 0.643 & 4 & 0.392 & 4 & 0.436 & 2 & 0.303 & 4 \\
\hline B50 & 0.744 & 2 & 0.741 & 2 & 0.837 & 5 & 0.234 & 5 & 0.198 & 5 \\
\hline B75 & 0.921 & 1 & 0.8 & 1 & 0.274 & 1 & 0.254 & 4 & 0.34 & 3 \\
\hline $\mathrm{Bl} 00$ & 0.345 & 3 & 0.68 & 3 & 0.54 & 3 & 0.323 & 3 & 0.55 & 1 \\
\hline
\end{tabular}

\begin{tabular}{|c|c|c|c|c|c|}
\hline \multicolumn{7}{|c|}{ Table 12: Siv alues of altematives at different load } \\
\hline Blend & 20\%load & 40\%load & 60\%load & 80\%load & 100\%oad \\
\hline B0 & 0.649 & 0.659 & 0.312 & 0.249 & 0.613 \\
\hline B25 & 0.886 & 0.696 & 0.624 & 0.149 & 0.454 \\
\hline B50 & 0.277 & 0.508 & 0.044 & 0.876 & 0.597 \\
\hline B75 & 0.158 & 0.232 & 0.947 & 0.772 & 0.860 \\
\hline B100 & 0.669 & 0.448 & 0.376 & 0.520 & 0.403 \\
\hline
\end{tabular}

\begin{tabular}{|c|c|c|c|c|c|}
\hline \multicolumn{7}{|c|}{ Table 10: Distance of alternative from NIS D ? } \\
\hline Blend & $20 \%$ load & 40\% & 60\%ad & 80\%load & $100 \%$ oad \\
\hline B0 & 0.004 & 0.02 & 0.01 & 0.015 & 0.011 \\
\hline B25 & 0.005 & 0.019 & 0.006 & 0.009 & 0.006 \\
\hline B50 & 0.022 & 0.021 & 0.013 & 0.004 & 0.003 \\
\hline B75 & 0.029 & 0.024 & 0.005 & 0.005 & 0.007 \\
\hline B100 & 0.011 & 0.023 & 0.009 & 0.007 & 0.012 \\
\hline
\end{tabular}

\section{RESULTS}

Applying the approaches of TOPSIS and VIKOR methods to calculate the best alternative blend results are represented in table (15-16). Both techniques acquire the B75 blend. Even though the first ranking is comparable in both techniques; the TOPSIS has a few restrictions over the VIKOR. It requires long computation to get the PIS and NIS of the criteria and

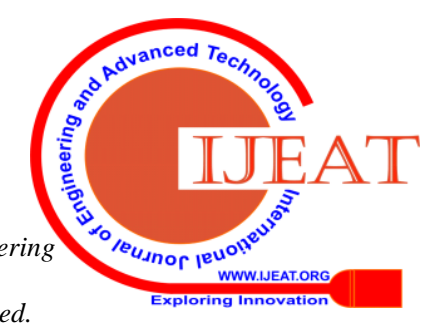




\begin{tabular}{|c|c|c|c|c|c|}
\hline \multicolumn{7}{|c|}{ Table 13: Ri values of a ltematives at different load } \\
\hline Blend & 20\%load & 40\%oad & 60\%load & 80\%oad & 100\%load \\
\hline B0 & 0.300 & 0.300 & 0.160 & 0.192 & 0.300 \\
\hline B25 & 0.300 & 0.284 & 0.250 & 0.075 & 0.279 \\
\hline B50 & 0.101 & 0.300 & 0.024 & 0.300 & 0.227 \\
\hline B75 & 0.116 & 0.156 & 0.300 & 0.288 & 0.291 \\
\hline B100 & 0.258 & 0.300 & 0.250 & 0.300 & 0.300 \\
\hline
\end{tabular}

division measures and closeness coefficient of the other alternatives. Increasingly computational planning is more, if the quantity of alternative and criteria increment.

\begin{tabular}{|c|c|c|c|c|c|}
\hline \multicolumn{7}{|c|}{ Table15: Ranking of TOPSIS } \\
\hline Blend & 20\%load & 40\%load & 60\%oad & 80\%load & 100\% oad \\
\hline B0 & 2 & 1 & 4 & 4 & 2 \\
\hline B25 & 1 & 2 & 2 & 5 & 4 \\
\hline B50 & 4 & 3 & 5 & 1 & 5 \\
\hline B75 & 5 & 5 & 1 & 2 & 1 \\
\hline B100 & 3 & 4 & 3 & 3 & 3 \\
\hline
\end{tabular}

\begin{tabular}{|c|c|c|c|c|c|}
\hline \multicolumn{7}{|c|}{ Tablel6: Ranking of VIK0R } \\
\hline Blend & 20\%load & 40\%load & 60\%load & 80\%load & 100\% oad \\
\hline B0 & 5 & 5 & 2 & 1 & 2 \\
\hline B25 & 4 & 4 & 4 & 2 & 4 \\
\hline B50 & 2 & 2 & 1 & 5 & 5 \\
\hline B75 & 1 & 1 & 5 & 4 & 3 \\
\hline B100 & 3 & 3 & 3 & 3 & 1 \\
\hline
\end{tabular}

\section{CONCLUSION}

In IC engines, selection of the best blend of biodiesel is an important issue. In a multi dimensional point of view, the best blend can be performing different number of experimental value. In this way, the MCDM techniques are essential for solving this issue. TOPSIS and VIKOR techniques are used to select the best possible candidate out of all alternative blends. It was found that B75 is the best blend which should be used in IC engine. This indicates that if design engineer use B75 blend in IC engine, the performance of engine would be better.

\section{REFERENCES}

1. Liu H, Hu B and Jin C. key fuel properties and engine performances of diesel ethanol blends, using tetra hydro furan as surfactant fuel, 184, 2016, 440-8.

2. Sahoo.P.K, Das.L.M, Babu M.K.G, Arora.P, Singh V.P, Kumar N.R, and Varyani T.S. Comparative evaluation of performance and emission characteristics of Jatropha, Karanja and polanga based biodiesel as fuel in a tractor engine fuel, 88, 2009, 1698-1707.

3. Mahla, S. K., Parmar, K. S., Singh, J., Dhir, A., Sandhu, S. S., \& Chauhan, B. S. Trend and time series analysis by ARIMA model to predict the emission and performance characteristics of biogas fuelled compression ignition engine energy sources part A recovery, utilization and environmental effects, 2019, 1-12, doi:10.1080/15567036.2019.1670286.

4. Chauhan, B. S., Kumar, N., Cho, H. M., \& Lim, H. C. A study on the performance and emission of a diesel engine fuelled with Karanja biodiesel and its blends Energy, 56, 2013, 1-7, doi:10.1016/j.energy.2013.03.083.

5. Hossain, A. K., \& Davies, P. A. Plant oils as fuels for Compression Ignition engines: A technical review and life-cycle analysis. Renewable Energy, 35(1), 2010, 1-13, doi:10.1016/j.renene.2009.05.009.

6. Sivaraja, C. M., \& Sakthivel, G. Compression ignition engine Performance modelling using hybrid MCDM techniques for the selection of optimum fish oil biodiesel blend at different injection timings $\quad$ Energy, 139, 2017, 118-141,doi:10.1016/j.energy.2017.07.134

7. Reinemann. D.J. Biodiesel present state and outlook in Wisconsin. USA: Department of Biological Systems Engineering, University of Wis cons in Extension. doug.reinemann@wisc.edu (608), 2007, 262-0223.

8. Chauhan, B. S., Singh, R. K., Cho, H. M., \& Lim, H. C. A review of Practice of diesel fuel blends using alternative fuels Renewable and Sustainable Energy, 59, 2016, 1358-1368. doi:10.1016/j.rser.2016.01.062

9. Kumar N, Varun, Kumar.A. Biodiesel as an alternative fuel for CI engines as Environmental effect. Indian Journal of Science and Technology; 3, 2013, 602- 606.

10. Vats U, Chaudhary R, Kumar. S, Giri. A, \& Kumar. S. Comparative Study of Emission and Combustion Characteristics of Biodiesel, Biodiesel Blends and Various Fuel Additives, Corpus ID: 160008137.

11. Saiful.Md, Salehd, Mofijur, M., Rasul, M.G \& Hyde, J. Study on Emission and Performance of Diesel Engine Using Castor Recent Developments Internal Combustion Engine Performance and Emissions Fuelled with Biodiesel-Diesel-Ethanol Blends. Procedia Engineering, 105, 2015, 658-664, doi: 10.1016/ j.proeng. 2015.05.045.

12. Agarwal, A. K. \& Das, L. M. Biodiesel Development and Characterization for Use as a Fuel in Compression Ignition Engines. Journal of Engineering for Gas Turbines and Power, 123(2), 2001, 440, doi:10.1115/1.1364522.

13. Imran, H., Khan, A.,Sujan, A., Islam, M., Niher, R \& Chowdhury, A. utilization of Karanja as a major raw material for the production of biodiesel Dhaka University Journal of science, 60(2), 2012, 203-207, doi.org/10.3329/dujs.v60i2.11506.

14. S.K. Hoekman, A. Broch, C. Robbins, E. Ceniceros, M. Natarajan. Review of biodiesel composition properties and specification renewable sustainable energy rev., 16, (2012), 143-169.

15. Bajpai, S., Sahoo, P. K., \& Das, L. M. Feasibility of blending Karanja vegetable oil in petrol diesel and utilization in a DI engine fuel, 88(4), 2009, 705-711, doi:10.1016/j.fuel.2008.09.01.1.

16. Ramesh, W. V \& Sakthivel, G. Selection of optimum fuel blend in an IC engine using Fahp-Promethee. IOP conference series 2018, 335-340, doi:10.1016/j.fuel.2004.09.016

17. Maheswari N, Balaji C, Ramesh A ."A non linear regression based multi objective optimization of parameters based on experimental data from an IC engine fuelled with biodiesel blends." Biomass Bio energy 35(2):, 2011, 2171-2183.

18. Shi, Y., Reitz, R. Optimization of a heavy duty compression ignition engine fueled with diesel and gasoline like fuels. Fuel, 89(11):3416-3430. doi:10.1016/j.fuel. 2010.02.023. 
19. José D. Martinez-Morales Eliva R. Palacios-Hernandez, Gerardo A. Velazqez-Carrillo. Modeling and multi-objective optimization of a gasoline engine using neural networks and evolutionary algorithms $\mathrm{J}$ Zhejiang University-Science A (Applied Physics \& Eng) 2013 14, 9 :657-670.

20. Chen Zheng, He Ping \& Chen Yan. A mathematical model using artificial neural networks to forecast shares tendencyll Applied Mathematics and Computation, 1999, 99, 71-76

21. Win, Z., Gakkhar, R. P., Jain, S. C., and Bhattacharya, M. Investigation of diesel engine operatingand injection system parameters for low noise, emissions and fuel consumption using Taguchi methods. J. Automobile. Eng., 2005, 219, 10, 1237-1251.

22. Ganapathy, T., Murugesan, K., and Gakkhar, R. P. Performance optimization of Jatropha biodieselengine model using Taguchi approach. Appl. Energy, 2009, 86, 11, 2476 - 2486.

23. Vijayakumar, P.C.Mukesh Kumar, E. Sankaranarayanan , B.Babuji. Evaluation of numerical model of performance and emission on bio-fuelled internal combustion engine ,International Journal of Applied Engineering Research, 2015, Vol. 10 No.85.

24. Pandian M., Sivapirakasam S.P and Udayakumar M. Investigation on the effect of injection system parameters on performance and emission characteristics of a twin cylinder compression ignition direct injection engine fuelled with pongamia biodiesel-diesel blend using response surface methodology. Applied Energy, 2011, vol.88, issue 8, 2663-2676, pii/S0306-2619, 11 00087-0.

25. Bharathiraja.M;.Venkatachalam .R; N. Prasanna.N. Experimental and mathematical investigation on performance and emission characteristics of ethanol fumigation in a single cylinder diesel engine of_Ethanol_Fumigation_in_a_Single_Cylinder Diesel_Engine. Asian Journal of Research in Social Sciences and Humanities Vol. 7, No. 1, January 2017, pp. 632-652.ISSN 2249-7315A Journal Indexed in Indian Citation Index doi number:10.5958/2249-7315.2016.01398.8.

26. Balafoutis A.T, Papadakis.G, Fountas .S, Dikopoulou .Z, \& Papageorgiou E. Sunflower oil fuel for diesel engines: an experimental investigation and optimum engine setting evaluation using a multi-criteria decision making approach, llcissn: 1543-5075 print / 1543-5083 online doi: 10.1080/15435075.2013.777912.

27. Sakthivel, G., Ilangkumaran, M., Nagarajan, G., Priyadharshini, G. V., Dinesh Kumar, S., Satish Kumar, S.Thilakavel, T. (2013). Multi-criteria decision modelling approach for biodiesel blends selection based on GRA-TOPSIS analysis. International Journal of Ambient $\quad$ Energy, 35(3), 139-154. doi:10.1080/01430750.2013.789984.

28. Akbari A. A , Goharimanesh M, Ali Lashkaripour, . Objective of optimization of biodiesel production by using genetic algorithm. Tamkang Journal of Science and Engineering, Volume (19), No (2), Year (2016-6), Pages 117-124.

29. Etghani M. M., Akbari M., Shojaeefard M. H., Khalkhali A. and Ghobadian B. Artificial neural networks based prediction of performance and exhaust emissions in direct injection engine using castor oil biodiesel-diesel blends, doi.org/10.1063/1.4769200.

30. Liu Bo \& Fuwu Yan \& Jie Hu \& Richard Fiifi Turkson \& Feng Lin, 2016. "Modeling and Multi-Objective Optimization of NO $x$ Conversion Efficiency and NH 3 Slip for a Diesel Engine," Sustainability, MDPI, Open Access Journal, vol. 8(5), pages 1-13, May.

31. Gaikwad A., Sakthivel G, Ilangkumaran M,. A hybrid multi-criteria decision modeling approach for the best biodiesel blend selection based on ANP-TOPSIS analysis doi.org/10.1016/j.asej.2014.08.003.

32. Lotfan S, Ghiasi RA, Fallah M, Sadeghi MH. ANN-based modeling and reducing dual-fuel engine's challenging emissions by multi-objective evolutionary algorithm NSGA-II. Applied Energy 2016; 175:91-9. doi.org/10.1016/j.apenergy.2016.04.099.

33. Mohammadhassani J, Khalilarya S, Dadvand A, Solimanpur M. Prediction and reduction of diesel engine emissions using a combined ANN-ACO method. Applied Software Computer J 2015; 34: 139-50. doi.org/10.1016/j.asoc.2015.04.059.

34. Pohit, G., \& Misra, D. Optimization of Performance and Emission Characteristics of Diesel Engine with Biodiesel Using Grey-Taguchi Method. Journal of Engineering, 2013, 1-8, doi:10.1155/2013/915357.

35. Çalışkan, H., Kurşuncu, B., Kurbanoğlu, C \& Güven, Ş. Y. Material selection for the tool holder working under hard milling conditions using different multi-criteria decision making methods. Materials and design, 45, 2013, 473-479, doi:10.1016/j.matdes.2012.09.042.

36. Gupta A, Kumar S. Flow shop scheduling decisions through Techniques for Order Preference by Similarity to an Ideal Solution (TOPSIS), 2016, doi.org/10.4995/ijpme.2016.4102.
37. Agarwal M, Kumar.S \& Chauhan B.S. Diesel engine performance with Karanja biodiesel oil by using TOPSIS method. International conference of advance research and innovation, 2020, SSRN-id3577579.

\section{AUTHORS PROFILE}

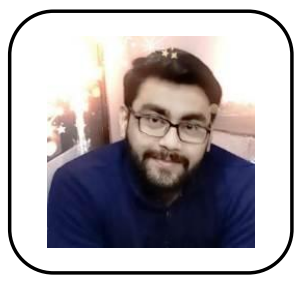

Mukul Agarwal is currently a $2^{\text {nd }}$ year M.tech student in the Department of Mechanical Engineering at MIET Meerut. He has received his B.E degree in Mechanical Engineering from S.D. college of Engineering and Technology from Muzaffarnagar.

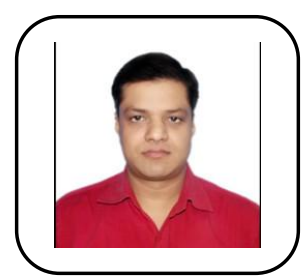

Shailendra Kumar Tyagi is working as an Assistant Professor in the Department of Mechanical Engineering, MIET, Meerut. He has received M.Tech Degree from National Institute of Technology Hamirpur. 